\title{
Effect of the Grain Size of the Soil on the Measured Activity and Variation in Activity in Surface and Subsurface Soil Samples
}

\author{
Huda Al-Sulaiti ${ }^{\text {ab }}$, Tabassum Nasir*ac ${ }^{*}$ Patrick Henry Regana ${ }^{a}$ David Bradley ${ }^{\text {a }}$ Khulud Al-Mugren ${ }^{\text {ad }}$, \\ Nasser Alkhomashi ${ }^{\mathrm{e}}$, Nawras Al-Dahan ${ }^{\text {af }}$, Muftah Al-Dosari ${ }^{\mathrm{b}}$, Sayed Jamal Bukhari ${ }^{\mathrm{g}}$, Marcus \\ Matthews $^{\mathrm{h}}$, Todsadol Santawamaitre ${ }^{\mathrm{a}}$, Doendara Malain ${ }^{\mathrm{a}}$ and Ahmad Habib ${ }^{\mathrm{a}}$ \\ ${ }^{\mathrm{a} C e n t r e ~ f o r ~ N u c l e a r ~ a n d ~ R a d i a t i o n ~ P h y s i c s, ~ D e p a r t m e n t ~ o f ~ P h y s i c s, ~ U n i v e r s i t y ~ o f ~ S u r r e y, ~}$ \\ Guildford GU2 7XH, United Kingdom \\ ${ }^{b}$ Radiation Protection and Chemicals Department, Ministry of Environment, P.O. Box 7634, Doha, Qatar \\ ${ }^{c}$ Department of Physics, Gomal University, Dera Ismail Khan, Pakistan \\ ${ }^{d}$ Physics Department, Faculty of Sciences, Princess Nora Bint Abdul Rahman University, Riyadh, Saudi Arabia \\ ${ }^{\circ}$ King Abdulaziz City of Science and Technology (KACST), P.O. Box 6086, Riyadh 11442, Saudi Arabia \\ fDepartment of Physics, College of Science, University of Kerbala, Kerbala, Iraq \\ ${ }^{\mathrm{g}}$ Information Technology Department, Ministry of Environment, P.O. Box 7634, Doha, Qatar \\ ${ }^{\mathrm{h}}$ Centre of Environmental Health Engineering, Department of Civil Engineering, University of Surrey, \\ Guildford GU2 7XH, United Kingdom
}

(received July 22, 2013; revised November 1, 2013; accepted November 5, 2013)

\begin{abstract}
Correlation between grain size and activity concentrations of soils and concentrations of various radionuclides in surface and subsurface soils has been measured for samples taken in the State of Qatar by gamma-spectroscopy using a high purity germanium detector. From the obtained gamma-ray spectra, the activity concentrations of the ${ }^{238} \mathrm{U}\left({ }^{226} \mathrm{Ra}\right)$ and ${ }^{232} \mathrm{Th}\left({ }^{228} \mathrm{Ac}\right)$ natural decay series, the long-lived naturally occurring radionuclide ${ }^{40} \mathrm{~K}$ and the fission product radionuclide ${ }^{137} \mathrm{Cs}$ have been determined. Gamma dose rate, radium equivalent, radiation hazard index and annual effective dose rates have also been estimated from these data. In order to observe the effect of grain size on the radioactivity of soil, three grain sizes were used i.e., smaller than $0.5 \mathrm{~mm}$; smaller than $1 \mathrm{~mm}$ and greater than $0.5 \mathrm{~mm}$; and smaller than $2 \mathrm{~mm}$ and greater than $1 \mathrm{~mm}$. The weighted activity concentrations of the ${ }^{238} \mathrm{U}$ series nuclides in $0.5-2 \mathrm{~mm}$ grain size of sample numbers was found to vary from $2.5 \pm 0.2$ to $28.5 \pm 0.5 \mathrm{~Bq} / \mathrm{kg}$, whereas, the weighted activity concentration of ${ }^{40} \mathrm{~K}$ varied from $21 \pm 4$ to $188 \pm 10 \mathrm{~Bq} / \mathrm{kg}$. The weighted activity concentrations of ${ }^{238} \mathrm{U}$ series and ${ }^{40} \mathrm{~K}$ have been found to be higher in the finest grain size. However, for the ${ }^{232} \mathrm{Th}$ series, the activity concentrations in the 1-2 mm grain size of one sample were found to be higher than in the 0.5-1 $\mathrm{mm}$ grain size. In the study of surface and subsurface soil samples, the activity concentration levels of ${ }^{238} \mathrm{U}$ series have been found to range from $15.9 \pm 0.3$ to $24.1 \pm 0.9 \mathrm{~Bq} / \mathrm{kg}$, in the surface soil samples $(0-5 \mathrm{~cm})$ and $14.5 \pm 0.3$ to $23.6 \pm 0.5 \mathrm{~Bq} / \mathrm{kg}$ in the subsurface soil samples $(5-25 \mathrm{~cm})$. The activity concentrations of ${ }^{232} \mathrm{Th}$ series have been found to lie in the range $5.7 \pm 0.2$ to $13.7 \pm 0.5 \mathrm{~Bq} / \mathrm{kg}$, in the surface soil samples $(0-5 \mathrm{~cm})$ and $4.1 \pm 0.2$ to $15.6 \pm 0.3 \mathrm{~Bq} / \mathrm{kg}$ in the subsurface soil samples $(5-25 \mathrm{~cm})$. The activity concentrations of ${ }^{40} \mathrm{~K}$ were in the range $150 \pm 8$ to $290 \pm 17 \mathrm{~Bq} / \mathrm{kg}$, in the surface soil samples $(0-5 \mathrm{~cm})$ and $129 \pm 7$ to $299 \pm 14 \mathrm{~Bq} / \mathrm{kg}$, in the subsurface soil samples $(5-25 \mathrm{~cm})$. The activity concentrations of ${ }^{238} \mathrm{U}$ series, ${ }^{232} \mathrm{Th}$ series and ${ }^{40} \mathrm{~K}$ in the surface and deep soil samples are approximately same. The ${ }^{137} \mathrm{Cs}$ activity concentration levels in surface soil samples in four sites were found to be higher than those observed for the soil samples that been collected at a depth of $5-25 \mathrm{~cm}$. They ranged from $1.65 \pm 0.22$ to $19.0 \pm 0.9 \mathrm{~Bq} / \mathrm{kg}$, in the surface soil samples $(0-5 \mathrm{~cm})$ and $0.5 \pm 0.2$ to $15.4 \pm 0.7 \mathrm{~Bq} / \mathrm{kg}$, in the subsurface soil samples $(5-25 \mathrm{~cm})$.
\end{abstract}

Keywords: annual effective dose rate, gamma-spectroscopy, grain size, surface and subsurface soil, radiation hazard index, radium equivalent

\section{Introduction}

Naturally occurring radioactivity can be found in certain industrial materials like ores and minerals (O'Brien, 2007). Radionuclides in naturally-occurring radioactive

*Author for correspondence; E-mail: tabassum642003@yahoo.com material (NORM) include primordial radionuclides that are naturally present in the rocks and minerals of the earth's crust and cosmogenic radionuclides produced by interactions of cosmic nucleons with target atoms in the atmosphere and in the earth. The radionuclides of particular interest are ${ }^{238,235} \mathrm{U}$, and ${ }^{232} \mathrm{Th}$ and their 
decay progeny, and the primordial radionuclide ${ }^{40} \mathrm{~K}$. Man-made radionuclides ${ }^{60} \mathrm{Co},{ }^{90} \mathrm{Sr}$ and ${ }^{137} \mathrm{Cs}$ are produced following nuclear fission in nuclear reactors or atomic weapons test fallout. Tremendous amounts of ${ }^{137} \mathrm{Cs}$ were released into the atmosphere by open air nuclear bomb tests conducted during 1950s and 1960s and by the Chernobyl nuclear disaster occurred in 1986. Since the released ${ }^{137} \mathrm{Cs}$ had spread out over the world and deposited on the ground, the most surface soils in the world generally have substantial inventory of ${ }^{137} \mathrm{Cs}$ (Park et al., 2013).

The elevated level of activity concentration in soil in some parts of the world may require taking action to protect humans living in dwellings built on these areas. The IAEA concluded that it is not necessary to apply regulatory control for activity concentrations below $1 \mathrm{~Bq} / \mathrm{g}$. If the activity concentrations are at this level or above, activity may still be exempted from regulatory controls if occupational exposure is found to be less than $1 \mathrm{mSv} / \mathrm{y}$ (IAEA, 2004). The average global effective dose rate to members of public from soil with weighted mean activity concentrations of $33 \mathrm{~Bq} / \mathrm{kg}, 45 \mathrm{~Bq} / \mathrm{kg}$ and $420 \mathrm{~Bq} / \mathrm{kg}$ for ${ }^{238} \mathrm{U},{ }^{232} \mathrm{Th}$, and ${ }^{40} \mathrm{~K}$, respectively is $0.460 \mathrm{mSv} / \mathrm{y}$ (UNSCEAR, 2000).

External gamma dose estimation due to NORM is important because this may contribute significantly, to the total annual individual dose. The doses can vary considerably depending on the ${ }^{238} \mathrm{U}$ and ${ }^{232} \mathrm{Th}$ (and their daughter products) and ${ }^{40} \mathrm{~K}$ concentrations present in the local geology and overlying soils (Rafique et al., 2011; Quindos et al., 1994; Radhakrishna et al., 1993).

Previous studies indicate that the radioactivity of the soil is related to the grain size i.e., soil radioactivity decreases with sand content in soil and increases with clay content. If the radium atoms are present only on the surface of the soil particles, the radium concentration is inversely proportional to the radius of the particles, whereas, if the radium is uniformly distributed throughout the soil grains, the radium concentration is independent of grain size (Kainan et al., 2004).

Depth profile studies show that the ${ }^{137} \mathrm{Cs}$ activity decreases with the increasing soil depth, and it is below detection limit for depths more than $25 \mathrm{~cm}$ (Karunakara et al., 2001).

The objective of this study was to observe the effect of grain size on the radioactivity of soil and variation in radioactivity in surface and subsurface soil samples.
This will provide a baseline data for the radioactivity concentration in Qatarian soil. Such data can be used to assess the biological effect of natural radiation in the environment and detect any significant future artificial release of radioactive radionuclides (Chen et al., 2005). Such studies are also used to set national standards in the light of global recommendations. On the national level, this research will contribute to the establishment of Qatarian national standards for the levels of natural radioactivity.

\section{Materials and Methods}

Sample collection and preparation. Soil samples were collected from sampling points located at regular intervals of 1 per $5 \mathrm{~km}^{2}$ square grid from the State of Qatar, using Qatar national grid (QNG) system. Preliminary reports on the determination of natural radioactivity levels in the State of Qatar and a report on the determination of the natural radioactivity levels in northwest of Dukhan (an area known for its oil fields) in the State of Qatar, have been earlier (Al-Sulaiti et al., 2012; 2011; 2010; Nasir et al., 2012). The State of Qatar is a peninsula with a total area of $11,437 \mathrm{~km}^{2}$, which lies over a geological formation comprising a sequence of limestone, chalk, clay and gypsum (Al-Sulaiti, 2011; MOFA, 2007).

In earlier study (Al-Sulaiti et al., 2010), one sample among the six showed mean activity concentration of ${ }^{238} \mathrm{U}$ as $213.9 \pm 1.4 \mathrm{~Bq} / \mathrm{kg}$, which is significantly, higher than the world average value of $33 \mathrm{~Bq} / \mathrm{kg}$. This sample was collected from an in shore oil field in the northwest of Qatar. Therefore, for the present study three more samples were collected from this area to investigate the correlation between the activity concentration and the grain size (Fig. 1, set 2). Moreover, the soil samples discussed in the preliminary report were collected from depths between 5 and $15 \mathrm{~cm}$, and the activity concentration of the artificial man-made radionuclide, ${ }^{137} \mathrm{Cs}$ in one sample has found to be $20.42 \pm 0.50 \mathrm{~Bq} / \mathrm{kg}$. Therefore, top soil samples $(0-5 \mathrm{~cm})$ and deeper soil samples $(5-25 \mathrm{~cm})$ were collected from 7 sampling points from the northwest of Qatar (Fig. 1, set 1) in order to investigate the correlation between the distribution of the radionuclides ${ }^{226} \mathrm{Ra},{ }^{228} \mathrm{Ac},{ }^{40} \mathrm{~K}$ and ${ }^{137} \mathrm{Cs}$ in surface and sub surface soil samples. Approximately, $1.5-2 \mathrm{~kg}$ of soil was collected at each sample point. Each sample was then transferred to a $2 \mathrm{~mm}$ sieve fitted in a collecting pan. The sieved samples were then filled into labelled polyethylene bags, sealed, packed in a box and shipped 


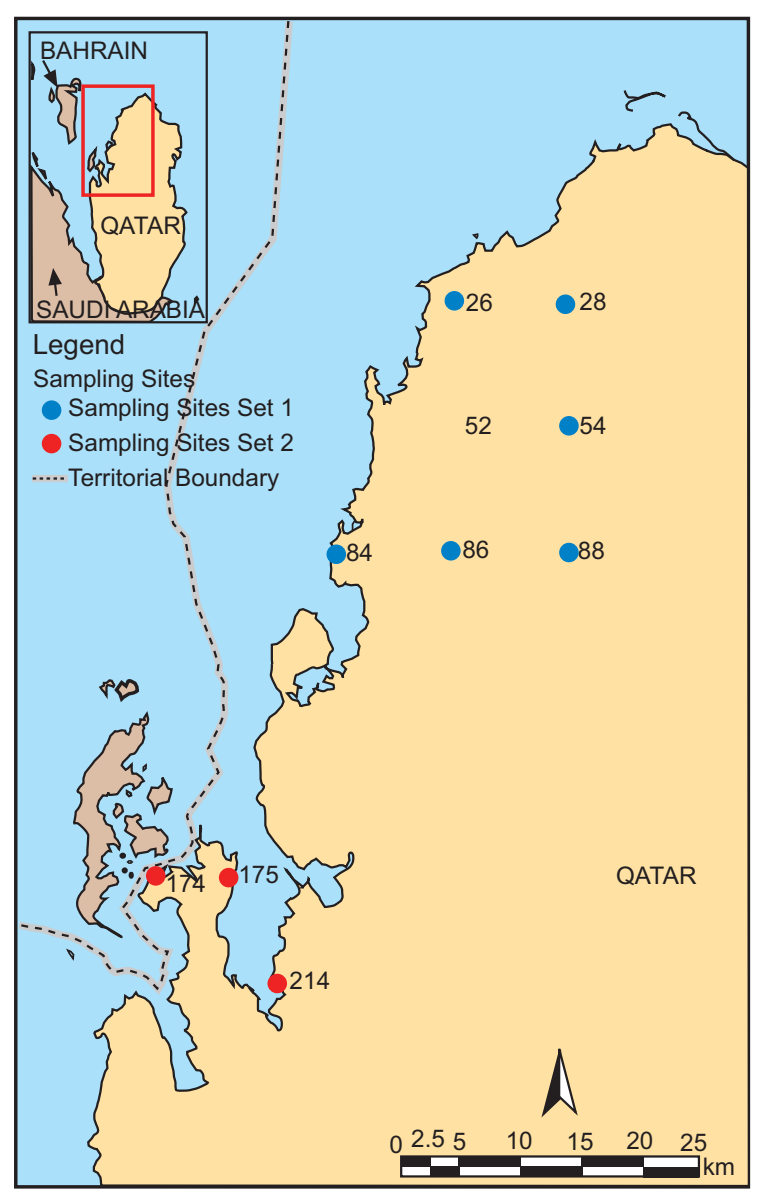

Fig. 1. The locations of the soil samples on the map of the State of Qatar. Samples of set 1 were used to study the distribution of radionuclide in surface and subsurface soil and samples of set 2 , were used to study the effect of grain size on activity concentration of soil. This map was created using ArcView 9 software (ESRI, 2005).

to the UK for analysis. The final sample preparation and all the gamma-ray measurements were performed in the low-background radiation detection laboratories of the Centre for Nuclear and Radiation Physics, situated within the Department of Physics at the University of Surrey.

The samples were dried in oven at a temperature of $60{ }^{\circ} \mathrm{C}$ for $24 \mathrm{~h}$ to remove the moisture. In order to observe the variation in activity in surface and sub surface soil samples, a $500 \mu \mathrm{m}$ mesh was used to sieve the samples, which were then weighed and transferred to $500 \mathrm{~mL}$ labelled Marinelli beakers. Similarly, to observe the correlation between the activity concentration and the grain size, 3 soil samples collected from different locations were segregated into three grain sizes. The grain sizes used were: (i) smaller than $0.5 \mathrm{~mm}$; (ii) smaller than $1 \mathrm{~mm}$ and greater than $0.5 \mathrm{~mm}$; and (iii) smaller than $2 \mathrm{~mm}$ and greater than $1 \mathrm{~mm}$. The samples were sealed and stored for about one month in order to reach radioactive secular equilibrium $(>7$ half-lives of ${ }^{222} \mathrm{Rn}$ and ${ }^{220} \mathrm{Rn}$ ).

Gamma-ray spectrometry. The soil samples were analysed using a high-resolution, low-background gammaray spectrometry system based on a p-type coaxial hyperpure germanium detector (HPGe). A crystal of $50 \mathrm{~mm}$ diameter was operated under a high voltage, bias of $+3000 \mathrm{~V}$ (DC). Low background was achieved by surrounding the detector with a cylindrical passive lead shield of about $10 \mathrm{~cm}$ thickness. The selected shaping time was $4 \mu \mathrm{s}$. Finally, the resultant spectral data was analysed using Canberra Genie software (Genie, 2000).

The performance of HPGe detector used was characterised by the energy calibration and its absolute full energy peak detection efficiency. Further details have been reported in other papers published by our collaboration (Al-Sulaiti et al., 2012; 2011; 2010; Nasir et al., 2012).

The samples were placed directly over the front face of the detector. The acquisition time for each sample was 1 day $(86,400 \mathrm{sec})$. The counting geometry of the samples and the standard sources used for efficiency calibration were kept constant. A variety of different gamma-ray energy transitions ranging from $\sim 100 \mathrm{keV}$ to $2.614 \mathrm{MeV}$, associated with the decay products of the ${ }^{238} \mathrm{U}$ and ${ }^{232} \mathrm{Th}$ decay series were analysed independently. The data were analysed under the assumption of secular equilibrium of the radionuclides within these samples. Activity concentrations of ${ }^{226} \mathrm{Ra},{ }^{214} \mathrm{~Pb}$ and ${ }^{214} \mathrm{Bi}$ were used to determine the activity concentration of ${ }^{238} \mathrm{U}$. The activity concentration of ${ }^{232} \mathrm{Th}$ was determined using gamma-ray transitions of ${ }^{228} \mathrm{Ac},{ }^{212} \mathrm{~Pb}$ and ${ }^{208} \mathrm{Tl}$. Gamma-ray peaks of ${ }^{40} \mathrm{~K}$ and ${ }^{137} \mathrm{Cs}$ were determined at 1461 and $662 \mathrm{keV}$, respectively. Background contributions were subtracted from the peak areas for the measured samples. The activity concentration $(\mathrm{Bq} / \mathrm{kg})$ was calculated using the following standard equation:

$$
\mathrm{A}=\mathrm{C}_{\mathrm{net}} / \gamma \times \varepsilon\left(\mathrm{E}_{\gamma}\right) \times \mathrm{m}
$$

where: 
$C_{n e t}$ is the net peak counts; $\gamma$ is the absolute gamma ray intensity for the specific energy photo peak; $\varepsilon\left(\mathrm{E}_{\gamma}\right)$ is the absolute full-energy peak efficiency of the germanium detector at this energy and $m$ is the mass of the sample in $\mathrm{kg}$.

The gamma dose rate (D) in the outdoor air at $1 \mathrm{~m}$ above ground level was calculated using the following equation (Al-Ghorabie, 2005; Singh et al., 2005):

$$
\mathrm{D}=\sum_{\mathrm{x}} \mathrm{A}_{\mathrm{x}} \times \mathrm{C}_{\mathrm{x}}
$$

where:

$\mathrm{A}_{\mathrm{x}}(\mathrm{Bq} / \mathrm{kg})$ is the mean activity of ${ }^{226} \mathrm{Ra},{ }^{232} \mathrm{Th}$ or ${ }^{40} \mathrm{~K}$, and $\mathrm{C}_{x}$ ( in units of $n \mathrm{~Gy} / \mathrm{h} / \mathrm{Bq} / \mathrm{kg}$ ) is the corresponding dose conversion factor. The dose conversion factors used in the calculation for ${ }^{226} \mathrm{Ra},{ }^{232} \mathrm{Th}$ and ${ }^{40} \mathrm{~K}$ were $0.461,0.623$ and 0.0414, respectively (Singh et al., 2005; UNSCEAR, 1993). The maximum permissible dose rate is $51 \mathrm{nGy} / \mathrm{h}$ (UNSCEAR, 1993).

The radium equivalent of the samples $(\mathrm{Bq} / \mathrm{kg})$ was calculated by the following equation (Rahman et al., 2009):

$$
\mathrm{Ra}_{\mathrm{eq}}=\left(\mathrm{A}_{\mathrm{K}} \times 0.077\right)+\left(\mathrm{A}_{\mathrm{U}}\right)+\left(\mathrm{A}_{\mathrm{Th}} \times 1.43\right)
$$

The permissible limit of $\mathrm{Ra}_{\mathrm{eq}}$ is $370 \mathrm{~Bq} / \mathrm{kg}$ in soil samples that contain ${ }^{238} \mathrm{U},{ }^{232} \mathrm{Th}$ and ${ }^{40} \mathrm{~K}$ measured in $\mathrm{Bq} / \mathrm{kg}$ (UNSCEAR, 2000).

The external hazard index was calculated by the following equation (Kumar et al., 2003; Amrani and Tahtat, 2001; Beretka and Mathew, 1985):

$$
H_{e x}=\left(A_{u} / 370\right)+\left(A_{T h} / 259\right)+\left(A_{K} / 4810\right)
$$

where:

$\mathrm{A}_{\mathrm{U}}, \mathrm{A}_{\mathrm{Th}}$ and $\mathrm{A}_{\mathrm{K}}$ are the specific activities of ${ }^{238} \mathrm{U},{ }^{232} \mathrm{Th}$ and ${ }^{40} \mathrm{~K}$, respectively.

The external hazard index should be below unity for the radiation hazard to be negligible (Ibrahim et al., 2009).

The annual effective dose equivalent was calculated by the following equation (UNSCEAR, 1988):

$$
\begin{aligned}
\operatorname{AEDE}(\mu \mathrm{S} v / \mathrm{y})= & \mathrm{D}(\mathrm{nGy} / \mathrm{h}) \times 8760(\mathrm{~h} / \mathrm{y}) \times \\
& 0.2 \times 0.7(\mathrm{~S} v / \mathrm{Gy}) \times 10^{-3}
\end{aligned}
$$

The world average annual effective dose equivalent (AEDE) from outdoor terrestrial gamma radiation is $460 \mu \mathrm{Sv} / \mathrm{y}$ (UNSCEAR, 2000).

\section{Results and Discussion}

Effect of the grain size of the soil on the radioactivity. The activity concentrations of soil samples can be influenced by the grain size of the samples (Hebinck et al., 2007). The activity concentrations of ${ }^{226} \mathrm{Ra},{ }^{214} \mathrm{~Pb}$, and ${ }^{214} \mathrm{Bi}$ (from the ${ }^{238} \mathrm{U}$ series), ${ }^{228} \mathrm{Ac},{ }^{212} \mathrm{~Pb}$ and ${ }^{208} \mathrm{Tl}$ (from the ${ }^{232} \mathrm{Th}$ series), ${ }^{40} \mathrm{~K}$ and ${ }^{137} \mathrm{Cs}$, along with statistical errors, in the soil samples investigated in the present study are presented in Table 1.

In Fig. 2, 3 and 4 the activity concentrations of ${ }^{238} \mathrm{U}$ series ${ }^{232} \mathrm{Th}$ series and ${ }^{40} \mathrm{~K}$ all appear to be correlated with the grain size for samples X174, X175 and 214, respectively. For all the three samples higher activities were noted for smaller grain sizes.

The weighted mean of the activity concentration of ${ }^{238} \mathrm{U}$ series and ${ }^{232}$ Th series in the $0.5 \mathrm{~mm}$ grain size of sample 214 were found to be about $28.5 \pm 0.5$ and $8.2 \pm 0.2 \mathrm{~Bq} / \mathrm{kg}$, respectively, higher than the values observed for $1 \mathrm{~mm}$ and $2 \mathrm{~mm}$ grain size. For the $1 \mathrm{~mm}$ and $2 \mathrm{~mm}$ grain sizes, the activity concentrations for the ${ }^{238} \mathrm{U}$ series were $19.2 \pm 0.4$ and $16.9 \pm 0.4 \mathrm{~Bq} / \mathrm{kg}$, while, the activity concentration of ${ }^{232} \mathrm{Th}$ series were $6.4 \pm 0.2$ and $5.6 \pm 0.2 \mathrm{~Bq} / \mathrm{kg}$, respectively. The activity concentrations of ${ }^{40} \mathrm{~K}$ were $188 \pm 10,154 \pm 9$ and $139 \pm 8 \mathrm{~Bq} / \mathrm{kg}$ for grain sizes $0.5,1$ and $2 \mathrm{~mm}$, respectively. Sample 214 comes from soil

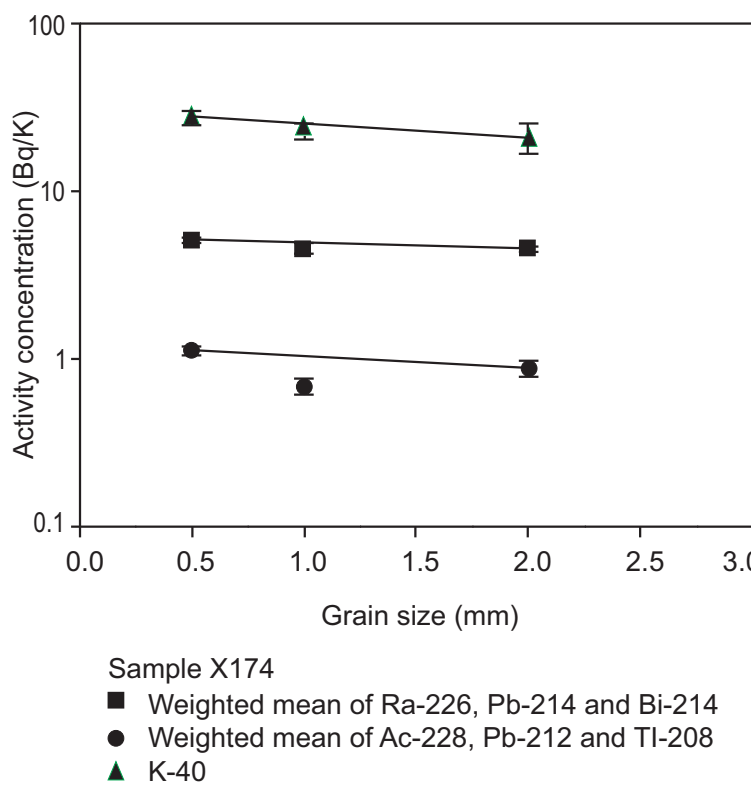

Fig. 2. The relationship between the weighted mean of the activity concentrations of ${ }^{238} \mathrm{U}$ series ${ }^{232} \mathrm{Th}$ series and ${ }^{40} \mathrm{~K}$ and the three different grain size for sample X174. 
Table 1. Activity concentrations (Bq/kg) of ${ }^{226} \mathrm{Ra},{ }^{214} \mathrm{~Pb}$ and ${ }^{214} \mathrm{Bi}\left({ }^{238} \mathrm{U}\right.$ series $),{ }^{228} \mathrm{Ac},{ }^{212} \mathrm{~Pb}$ and ${ }^{208} \mathrm{Tl}\left({ }^{232} \mathrm{Th}\right.$ series$)$, ${ }^{40} \mathrm{~K}$ and ${ }^{137} \mathrm{Cs}$, in the soil samples for different grain sizes

\begin{tabular}{|c|c|c|c|c|}
\hline \multirow[t]{2}{*}{ Samples } & \multirow{2}{*}{$\begin{array}{l}{ }^{238} \mathrm{U} \text { series } \\
\mathrm{WM} \text { of }{ }^{226} \mathrm{Ra}, \\
{ }^{214} \mathrm{~Pb} \text { and }{ }^{214} \mathrm{Bi}\end{array}$} & \multirow{2}{*}{$\begin{array}{l}{ }^{232} \mathrm{Th} \text { series } \\
\mathrm{WM} \text { of }{ }^{228} \mathrm{Ac}, \\
{ }^{212} \mathrm{~Pb} \text { and }{ }^{208} \mathrm{Tl}\end{array}$} & \multirow[t]{2}{*}{${ }^{40} \mathrm{~K}$} & \multirow[t]{2}{*}{${ }^{137} \mathrm{Cs}$} \\
\hline & & & & \\
\hline $\begin{array}{l}\text { Sample-X174 } \\
\text { mesh }<0.5 \mathrm{~mm}\end{array}$ & $5.08 \pm 0.18$ & $1.12 \pm 0.07$ & $27.2 \pm 2.8$ & $*$ \\
\hline $\begin{array}{l}\text { Sample-X174 } \\
1 \mathrm{~mm}>\text { mesh }>0.5 \mathrm{~mm}\end{array}$ & $4.61 \pm 0.34$ & $0.69 \pm 0.08$ & $22.9 \pm 2.5$ & $*$ \\
\hline $\begin{array}{l}\text { Sample-X174 } \\
2 \mathrm{~mm}>\text { mesh }>1 \mathrm{~mm}\end{array}$ & $4.54 \pm 0.18$ & $0.88 \pm 0.09$ & $20.9 \pm 4.1$ & $*$ \\
\hline $\begin{array}{l}\text { Sample-X175 } \\
\text { mesh }<0.5 \mathrm{~mm}\end{array}$ & $3.53 \pm 0.22$ & $1.82 \pm 0.11$ & $77.4 \pm 5.9$ & $*$ \\
\hline $\begin{array}{l}\text { Sample-X175 } \\
1 \mathrm{~mm}>\text { mesh }>0.5 \mathrm{~mm}\end{array}$ & $3.35 \pm 0.18$ & $1.10 \pm 0.09$ & $62.8 \pm 4.7$ & $0.23 \pm 0.18$ \\
\hline $\begin{array}{l}\text { Sample-X175 } \\
2 \mathrm{~mm}>\text { mesh }>1 \mathrm{~mm}\end{array}$ & $2.46 \pm 0.17$ & $1.55 \pm 0.12$ & $41.9 \pm 3.3$ & $*$ \\
\hline $\begin{array}{l}\text { Sample-214 } \\
\text { mesh }<0.5 \mathrm{~mm}\end{array}$ & $28.54 \pm 0.45$ & $8.20 \pm 0.21$ & $188 \pm 10$ & $0.69 \pm 0.28$ \\
\hline $\begin{array}{l}\text { Sample-214 } \\
1 \mathrm{~mm}>\text { mesh }>0.5 \mathrm{~mm}\end{array}$ & $19.22 \pm 0.40$ & $6.41 \pm 0.18$ & $154.0 \pm 8.5$ & $*$ \\
\hline $\begin{array}{l}\text { Sample-214 } \\
2 \mathrm{~mm}>\text { mesh }>1 \mathrm{~mm}\end{array}$ & $16.91 \pm 0.36$ & $5.55 \pm 0.18$ & $139.2 \pm 8.0$ & $0.36 \pm 0.17$ \\
\hline
\end{tabular}

* = below minimum detectable activity MDA.
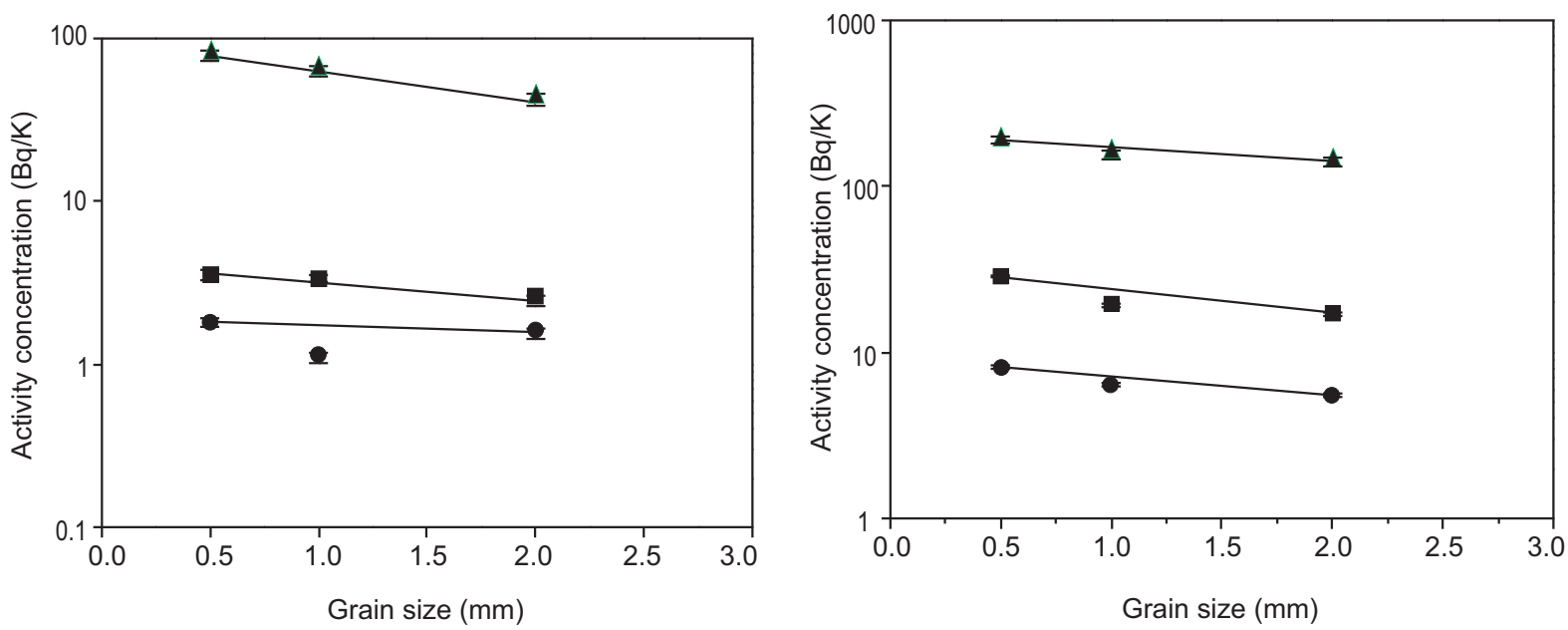

Sample X175

- Weighted mean of Ra-226, $\mathrm{Pb}-214$ and $\mathrm{Bi}-214$

- Weighted mean of Ac-228, Pb-212 and TI-208

A $\mathrm{K}-40$

Sample X 214

Weighted mean of Ra-226, Pb-214 and Bi-214

- Weighted mean of Ac-228, Pb-212 and Tl-208

A $\mathrm{K}-40$

Fig. 3. The relationship between the weighted mean of the activity concentrations of ${ }^{238} \mathrm{U}$ series ${ }^{232} \mathrm{Th}$ series and ${ }^{40} \mathrm{~K}$ and the three different grain size for sample X175.

Fig. 4. The relationship between the weighted mean of the activity concentrations of ${ }^{238} \mathrm{U}$ series ${ }^{232} \mathrm{Th}$ series and ${ }^{40} \mathrm{~K}$ and the three different grain size for sample 214 . 
overlying the dammad formation, from the middle Eocene period, which consists of shale, limestone and dolomite. It can be concluded that the finest grain size had the highest activity concentration (for sample 214 at least). The other two samples (X174 and X175) showed similar behaviour for the ${ }^{238} \mathrm{U}$ series and ${ }^{40} \mathrm{~K}$. However, for the ${ }^{232} \mathrm{Th}$ series, the activity concentrations in the $1-2 \mathrm{~mm}$ grain size were found to be higher than in the $0.5-1 \mathrm{~mm}$ grain size. This might be related to the soil type as both of them were collected from the same geological background. The underlying geology in the area, where those samples were collected belongs to sabkha deposits which consist of sand and silt flats.

The calculated absorbed dose rate, radium equivalent activity, the external hazard index and annual effective dose equivalent along with statistical errors from soil samples having different grain sizes are given in Table 2.

In Table 2, the calculated values of absorbed dose rate, radium equivalent activity, the external hazard index and annual effective dose equivalent were found to be higher for smaller grain sizes except for sample X174, where the absorbed dose rate, radium equivalent activity and annual effective dose equivalent were slightly higher for grain sizes $<2 \mathrm{~mm}$ and $>1 \mathrm{~mm}$, compared to grain size $<1 \mathrm{~mm}$ and $>0.5 \mathrm{~mm}$. This might be due to the relatively low content of ${ }^{232} \mathrm{Th}$, in this mesh size comparing with greatest mesh $(2 \mathrm{~mm}>$ mesh $>1 \mathrm{~mm})$.

Variation in activity in surface and sub surface soil samples. A comparison between the surface $0-5 \mathrm{~cm}$ soil samples and soil samples taken at depth of $5-25 \mathrm{~cm}$ was conducted in order to investigate the correlation between the distribution of the radionuclides ${ }^{226} \mathrm{Ra}$, ${ }^{228} \mathrm{Ac},{ }^{40} \mathrm{~K}$ and ${ }^{137} \mathrm{Cs}$ and layer depth. The activity concentrations of ${ }^{226} \mathrm{Ra}{ }^{214} \mathrm{~Pb}$ and ${ }^{214} \mathrm{Bi}$ (from the ${ }^{238} \mathrm{U}$ series), ${ }^{228} \mathrm{Ac},{ }^{212} \mathrm{~Pb}$ and ${ }^{208} \mathrm{Tl}$ (from the ${ }^{232} \mathrm{Th}$ series), ${ }^{40} \mathrm{~K}$ and ${ }^{137} \mathrm{Cs}$, along with statistical errors in surface and sub surface soil samples are presented in Table 3.

Figure 5 shows the weighted mean of the activity concentration for the individual activities as deduced from the observed gamma-ray transitions associated with the direct decays of ${ }^{226} \mathrm{Ra},{ }^{214} \mathrm{~Pb}$ and ${ }^{214} \mathrm{Bi}$ (from

Table 2. Dose rate (D) $(\mathrm{nGy} / \mathrm{h})$, radium equivalent activity $\left(\mathrm{Ra}_{\mathrm{eq}}\right)(\mathrm{Bq} / \mathrm{kg})$, external hazard index $\left(\mathrm{H}_{\mathrm{ex}}\right)$ and annual effective dose equivalent (AEDE) $(\mu \mathrm{S} v / \mathrm{y})$ from soil samples for different grain sizes

\begin{tabular}{|c|c|c|c|c|}
\hline Samples & $\begin{array}{l}\text { Dose rate } \\
\text { (D) }\end{array}$ & $\begin{array}{l}\text { Radium equivalent } \\
\text { activity }\left(\mathrm{Ra}_{\mathrm{eq}}\right)\end{array}$ & $\begin{array}{l}\text { External hazard } \\
\text { index }\left(\mathrm{H}_{\mathrm{ex}}\right)\end{array}$ & $\begin{array}{l}\text { Annual effective dose } \\
\text { equivalent (AEDE) }\end{array}$ \\
\hline $\begin{array}{l}\text { Sample-X174 } \\
\text { mesh }<0.5 \mathrm{~mm}\end{array}$ & $4.08 \pm 0.52$ & $8.6 \pm 1.1$ & $0.024 \pm 0.003$ & $5.01 \pm 0.64$ \\
\hline $\begin{array}{l}\text { Sample-X174 } \\
1 \mathrm{~mm}>\text { mesh }>0.5 \mathrm{~mm}\end{array}$ & $3.41 \pm 0.62$ & $7.2 \pm 1.3$ & $0.020 \pm 0.004$ & $4.19 \pm 0.76$ \\
\hline $\begin{array}{l}\text { Sample-X174 } \\
2 \mathrm{~mm}>\text { mesh }>1 \mathrm{~mm}\end{array}$ & $3.43 \pm 0.77$ & $7.3 \pm 1.6$ & $0.020 \pm 0.004$ & $4.20 \pm 0.94$ \\
\hline $\begin{array}{l}\text { Sample-X175 } \\
\text { mesh }<0.5 \mathrm{~mm}\end{array}$ & $6.06 \pm 0.70$ & $11.6 \pm 1.3$ & $0.033 \pm 0.004$ & $7.43 \pm 0.85$ \\
\hline $\begin{array}{l}\text { Sample-X175 } \\
1 \mathrm{~mm}>\text { mesh }>0.5 \mathrm{~mm}\end{array}$ & $4.87 \pm 0.60$ & $9.3 \pm 1.2$ & $0.026 \pm 0.003$ & $5.98 \pm 0.74$ \\
\hline $\begin{array}{l}\text { Sample-X175 } \\
2 \mathrm{~mm}>\text { mesh }>1 \mathrm{~mm}\end{array}$ & $3.89 \pm 0.51$ & $7.6 \pm 1.0$ & $0.021 \pm 0.003$ & $4.77 \pm 0.62$ \\
\hline $\begin{array}{l}\text { Sample- } 214 \\
\text { mesh }<0.5 \mathrm{~mm}\end{array}$ & $25.8 \pm 1.6$ & $53.4 \pm 3.3$ & $0.148 \pm 0.009$ & $31.57 \pm 1.9$ \\
\hline $\begin{array}{l}\text { Sample- } 214 \\
1 \mathrm{~mm}>\text { mesh }>0.5 \mathrm{~mm}\end{array}$ & $19.1 \pm 1.3$ & $39.2 \pm 2.6$ & $0.109 \pm 0.007$ & $23.4 \pm 1.5$ \\
\hline $\begin{array}{l}\text { Sample-214 } \\
2 \mathrm{~mm}>\text { mesh }>1 \mathrm{~mm}\end{array}$ & $16.9 \pm 1.2$ & $34.6 \pm 2.4$ & $0.096 \pm 0.007$ & $20.7 \pm 1.4$ \\
\hline
\end{tabular}


Table 3. Activity concentrations ( $\mathrm{Bq} / \mathrm{kg}$ ) of ${ }^{226} \mathrm{Ra},{ }^{214} \mathrm{~Pb}$ and ${ }^{214} \mathrm{Bi}\left({ }^{238} \mathrm{U}\right.$ series $),{ }^{228} \mathrm{Ac},{ }^{212} \mathrm{~Pb}$ and ${ }^{208} \mathrm{Tl}\left({ }^{232} \mathrm{Th}\right.$ series), ${ }^{40} \mathrm{~K}$ and ${ }^{137} \mathrm{Cs}$, in the surface and subsurface soil samples

\begin{tabular}{|c|c|c|c|c|}
\hline Samples & $\begin{array}{l}{ }^{238} \mathrm{U} \text { series } \\
\mathrm{WM} \text { of }{ }^{226} \mathrm{Ra} \\
{ }^{214} \mathrm{~Pb} \text { and }{ }^{214} \mathrm{Bi}\end{array}$ & $\begin{array}{l}{ }^{232} \mathrm{Th} \text { series } \\
\mathrm{WM} \text { of }{ }^{228} \mathrm{Ac}, \\
{ }^{212} \mathrm{~Pb} \text { and }{ }^{208} \mathrm{Tl}\end{array}$ & ${ }^{137} \mathrm{Cs}$ & ${ }^{40} \mathrm{~K}$ \\
\hline S-26 (Surface) & $19.62 \pm 0.34$ & $6.85 \pm 0.19$ & $11.57 \pm 0.54$ & $149.6 \pm 7.8$ \\
\hline S-28 (Surface) & $22.63 \pm 0.44$ & $15.69 \pm 0.18$ & $19.03 \pm 0.89$ & $290 \pm 15$ \\
\hline S-52 (Surface) & $15.93 \pm 0.30$ & $5.65 \pm 0.18$ & $3.35 \pm 0.23$ & $174.4 \pm 8.9$ \\
\hline S-54 (Surface) & $18.09 \pm 0.37$ & $10.30 \pm 0.35$ & $4.56 \pm 0.31$ & $208 \pm 10$ \\
\hline S-84 (Surface) & $17.73 \pm 0.34$ & $8.03 \pm 0.24$ & $*$ & $166.3 \pm 7.9$ \\
\hline S-86 (Surface) & $16.06 \pm 0.31$ & $6.08 \pm 0.16$ & $1.65 \pm 0.22$ & $150.3 \pm 7.8$ \\
\hline S-88 (Surface) & $24.11 \pm 0.91$ & $13.73 \pm 0.54$ & $7.80 \pm 0.84$ & $290 \pm 17$ \\
\hline D-26 (Subsurface) & $19.98 \pm 0.34$ & $7.02 \pm 0.20$ & $15.41 \pm 0.67$ & $154.9 \pm 8.2$ \\
\hline D-28 (Subsurface) & $23.63 \pm 0.50$ & $15.60 \pm 0.30$ & $14.58 \pm 0.62$ & $297 \pm 14$ \\
\hline D-52 (Subsurface) & $15.48 \pm 0.29$ & $5.33 \pm 0.17$ & $3.71 \pm 0.29$ & $179.5 \pm 9.1$ \\
\hline D-54 (Subsurface) & $18.63 \pm 0.43$ & $10.53 \pm 0.22$ & $3.10 \pm 0.36$ & $204 \pm 10$ \\
\hline D-84 (Subsurface) & $16.79 \pm 0.32$ & $7.66 \pm 0.19$ & $0.43 \pm 0.19$ & $164.0 \pm 8.5$ \\
\hline D-86 (Subsurface) & $14.51 \pm 0.29$ & $4.08 \pm 0.15$ & $0.51 \pm 0.16$ & $128.5 \pm 6.8$ \\
\hline D-88 (Subsurface) & $22.89 \pm 0.43$ & $15.16 \pm 0.29$ & $4.76 \pm 0.37$ & $299 \pm 14$ \\
\hline
\end{tabular}

$*=$ below minimum detectable activity MDA.

the ${ }^{238} \mathrm{U}$ series), ${ }^{228} \mathrm{Ac},{ }^{212} \mathrm{~Pb}$ and ${ }^{208} \mathrm{Tl}$ (from the ${ }^{232} \mathrm{Th}$ series) and the activity concentrations for ${ }^{40} \mathrm{~K}$ and ${ }^{137} \mathrm{Cs}$ in the surface and deep soil. The activity concentration

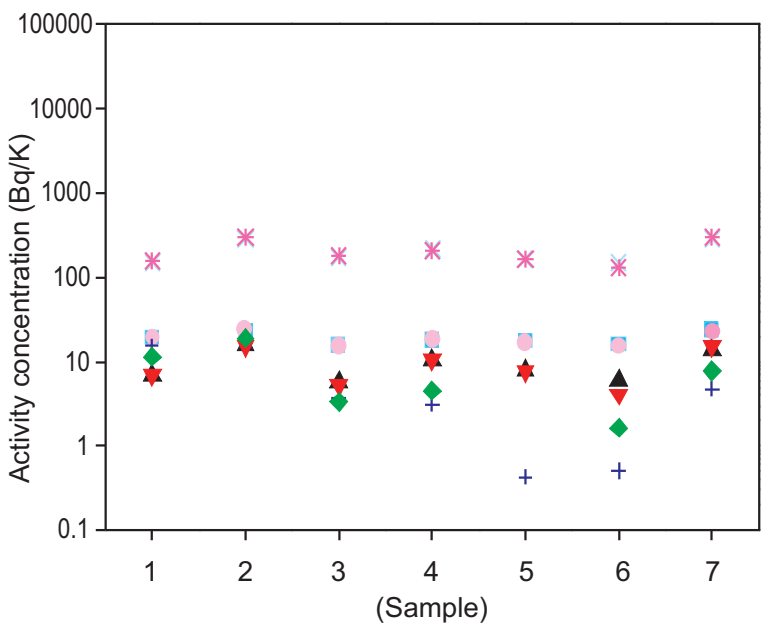

- Surface samples, weighted mean of Ra-226, $\mathrm{Pb}-214$ and $\mathrm{Bi}-214$ - Subsurface samples, weighted mean of Ra-226, Pb-214 and Bi-214

$\Delta$ Surface samples, weighted mean of Ac-228, Pb-212 and TI-208

$\nabla$ Subsurface samples, weighted mean of Ac-228, Pb-212 and TI-208

- Surface samples Cs-137

+ Subsurface samples Cs-137

X Surface samples K-40

* Subsurface samples K-40

Fig. 5. Activity concentrations levels of ${ }^{226} \mathrm{Ra}$, ${ }^{228} \mathrm{Ac},{ }^{40} \mathrm{~K}$ and ${ }^{137} \mathrm{Cs}$ for topsoil samples $0-5$ and soil samples taken at depths of $5-25 \mathrm{~cm}$. levels of ${ }^{238} \mathrm{U}$ decay products, ${ }^{232} \mathrm{Th}$ decay products and ${ }^{40} \mathrm{~K}$ in the surface and deep soil samples were similar. Activity concentrations of ${ }^{137} \mathrm{Cs}$ in surface soil samples in four sites were found to be higher than those observed for the soil samples that had been collected at a depth of 5-25 cm. This is possibly because ${ }^{137} \mathrm{Cs}$ accumulates in the top soil layers and dilutes in the deeper layers (Kim et al., 1997).

${ }^{137} \mathrm{Cs}$ exists in soil naturally only in trace amounts following the spontaneous fission of ${ }^{238} \mathrm{U}$. Measured values in the current work are therefore due to the artificially produced fission of ${ }^{238} \mathrm{U}$. Nuclear accidents, bombs test and nuclear weapons are the origins of ${ }^{137} \mathrm{Cs}$ contamination (Nasir et al., 2012).

According to IAEA, the amount of ${ }^{137} \mathrm{Cs}$ released during the Chernobyl accident on $26^{\text {th }}$ April 1986, was $0.09 \times$ $10^{18} \mathrm{~Bq}$ (IAEA, 1996). This tremendous amount of radioactive material was deposited over the entire northern hemisphere including the Middle East region. The half-life of ${ }^{137} \mathrm{Cs}$ is long enough $(\approx 30$ years $)$ to be traced for several tens of years.

In the current study, it is expected that this contamination is mainly due to Chernobyl accident because the samples were collected before Fukushima accident in April 2011. This conclusion can not be confirmed because of the lack of data available in the area under study, before 1986. 
Table 4. Dose rate $(D)(n G y / h)$, radium equivalent activity $\left(\mathrm{Ra}_{\mathrm{eq}}\right)(\mathrm{Bq} / \mathrm{kg})$, external hazard index $\left(\mathrm{H}_{\mathrm{ex}}\right)$ and annual effective dose equivalent $(\mu \mathrm{S} v / \mathrm{y})$ for surface and subsurface soil samples

\begin{tabular}{lllll}
\hline Samples & $\begin{array}{l}\text { Dose rate } \\
\text { (D) }\end{array}$ & $\begin{array}{l}\text { Radium equivalent } \\
\text { activity (Raeq) }\end{array}$ & $\begin{array}{l}\text { External hazard } \\
\text { index }\left(\mathrm{H}_{\mathrm{ex}}\right)\end{array}$ & $\begin{array}{l}\text { Annual effective } \\
\text { dose equivalent } \\
\text { (AEDE) }\end{array}$ \\
\hline S-26 (Surface) & $19.4 \pm 1.2$ & $39.9 \pm 2.5$ & $0.111 \pm 0.007$ & $23.8 \pm 1.5$ \\
S-28 (Surface) & $32.5 \pm 1.8$ & $65.3 \pm 3.6$ & $0.182 \pm 0.010$ & $39.9 \pm 2.2$ \\
S-52 (Surface) & $18.1 \pm 1.1$ & $36.2 \pm 2.3$ & $0.101 \pm 0.006$ & $22.2 \pm 1.4$ \\
S-54 (Surface) & $23.5 \pm 1.5$ & $47.4 \pm 3.0$ & $0.132 \pm 0.008$ & $28.9 \pm 1.8$ \\
S-84 (Surface) & $20.1 \pm 1.2$ & $40.9 \pm 2.4$ & $0.114 \pm 0.007$ & $24.6 \pm 1.5$ \\
S-86 (Surface) & $17.4 \pm 1.1$ & $35.3 \pm 2.2$ & $0.098 \pm 0.006$ & $21.3 \pm 1.3$ \\
S-88 (Surface) & $31.9 \pm 2.6$ & $64.1 \pm 5.1$ & $0.179 \pm 0.014$ & $39.2 \pm 3.1$ \\
D-26 (Subsurface) & $19.9 \pm 1.2$ & $40.9 \pm 2.5$ & $0.113 \pm 0.007$ & $24.4 \pm 1.5$ \\
D-28 (Subsurface) & $33.3 \pm 1.9$ & $66.7 \pm 3.7$ & $0.186 \pm 0.010$ & $40.8 \pm 2.3$ \\
D-52 (Subsurface) & $17.9 \pm 1.1$ & $35.7 \pm 2.2$ & $0.100 \pm 0.006$ & $21.9 \pm 1.4$ \\
D-54 (Subsurface) & $23.7 \pm 1.4$ & $48.0 \pm 2.9$ & $0.133 \pm 0.008$ & $29.1 \pm 1.7$ \\
D-84 (Subsurface) & $19.3 \pm 1.2$ & $39.2 \pm 2.4$ & $0.109 \pm 0.007$ & $23.7 \pm 1.4$ \\
D-86 (Subsurface) & $14.5 \pm 1.0$ & $29.3 \pm 2.0$ & $0.082 \pm 0.005$ & $17.7 \pm 1.2$ \\
D-88 (Subsurface) & $32.7 \pm 1.8$ & $65.5 \pm 3.6$ & $0.183 \pm 0.010$ & $40.1 \pm 2.2$ \\
\hline
\end{tabular}

Figure 6 shows the ratio of ${ }^{232} \mathrm{Th}$ to ${ }^{238} \mathrm{U}$ in topsoil and deeper samples. The slope of each trend line in this plot was used to deduce the activity ratio of ${ }^{232} \mathrm{Th}$ to ${ }^{238} \mathrm{U}$ (assuming radioactive equilibrium). This was found to be slightly higher in the deeper soil samples than the topsoil samples. The fitted line slopes were $1.20 \pm 0.21$ and $1.09 \pm 0.26$, respectively. This indicates that the activity concentrations of ${ }^{226} \mathrm{Ra}$, which was used to estimate the levels of ${ }^{238} \mathrm{U}$ may be (slightly) affected by the dissolution reactions in the topsoil samples. Since compounds of ${ }^{226} \mathrm{Ra}$ are soluble in water, radium nuclides are mobile and may be introduced along with any water, precipitate and leached out due to chemical pressure and temperature changes (Wilson, 1994).

The calculated absorbed dose rate, radium equivalent activity, the external hazard index and annual effective dose equivalent along with statistical errors for surface and subsurface soil samples are given in Table 4.

Table 4 indicates the calculated values of absorbed dose rate, radium equivalent activity, the external hazard index and annual effective dose equivalent were found to be approximately same for all the investigated surface and sub surface samples. This might be expected since these values depend on the activity concentration levels ${ }^{238} \mathrm{U}$ and ${ }^{232} \mathrm{Th}$ decay series and ${ }^{40} \mathrm{~K}$ in the soil and these were found to be almost the same in surface and subsurface soil, except for ${ }^{137} \mathrm{Cs}$, which is expected to be higher in the surface soil.

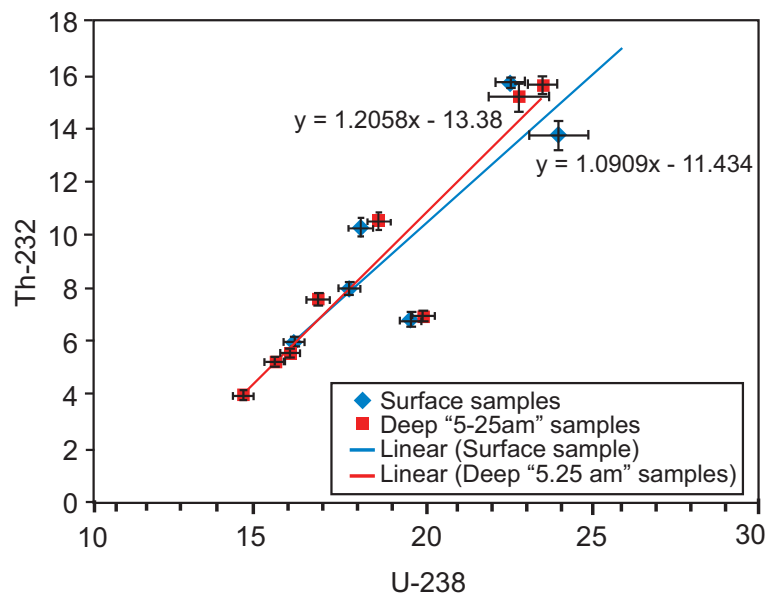

Fig. 6. The weighted mean of activity concentrations levels for ${ }^{232} \mathrm{Th}$, versus the weighted mean of activity concentration for ${ }^{238} \mathrm{U}$ for the 7 investigated samples.

\section{Conclusion}

It can be concluded from the weighted mean of the activity concentration of ${ }^{226} \mathrm{Ra},{ }^{228} \mathrm{Ac}$ and ${ }^{40} \mathrm{~K}$ in soil samples having different grain sizes that the finest grain size has the highest activity concentration. However, for ${ }^{232} \mathrm{Th}$ series, the activity concentrations in $2 \mathrm{~mm}$ grain size of two samples (X175 and 214) were found to be higher than for the $0.5-1 \mathrm{~mm}$ grain size.

The calculated values of absorbed dose rate, radium equivalent activity, the external hazard index and annual 
effective dose equivalent have been found higher for smaller grain sizes except for one sample (X174) where absorbed dose rate, radium equivalent activity and annual effective dose equivalent were calculated to be slightly higher for grain sizes $<2 \mathrm{~mm}$ and $>1 \mathrm{~mm}$ as compared to grain sizes $<1 \mathrm{~mm}$ and $>0.5 \mathrm{~mm}$.

The activity concentration levels of ${ }^{238} \mathrm{U}$ series, ${ }^{232} \mathrm{Th}$ series and ${ }^{40} \mathrm{~K}$ in the surface and deep soil samples are approximately same. The activity concentration levels of ${ }^{137} \mathrm{Cs}$ in surface soil samples in four sites have been found to be higher than those observed for the soil samples that had been collected at a depth of $5-25 \mathrm{~cm}$. As only 7 soil samples were analysed in the current work, it is suggested that a further study to be done on the radioactivity concentration of ${ }^{137} \mathrm{Cs}$ in the Qatarian topsoil, particularly after Fukushima accident in April 2011, in order to obtain more statistically significant picture of the radiological map of the Qatarian peninsula.

The calculated values of absorbed dose rate, radium equivalent activity, the external hazard index and annual effective dose equivalent have been found approximately same for all the investigated surface and sub surface samples except for sample 86, which has slightly lower values for sub surface soil.

\section{Acknowledgment}

Huda Al-Sulaiti acknowledges the financial support provided by the Ministry of Environment in Doha-Qatar and would also like to acknowledge the Minister of Environment, Mr. H.E. Abdulla bin Mubarak Al Moadhadi for his support.

Tabassum Nasir acknowledges the financial support received from the Higher Education Commission Islamabad, Pakistan, through HEC Post Doctoral Fellowship Program Phase-II (Batch-IV-2009). Todsadol Santawamaitre and Doendara Malain acknowledge financial support from the Royal Thai Government.

\section{References}

Al-Ghorabie, F.H.H. 2005. Measurements of environmental terrestrial gamma radiation dose rate in three mountainous locations in the western region of Saudi Arabia. Environmental Research, 98: 160166.

Al-Sulaiti, H., Nasir, T., Al Mugren, K.S., Alkhomashi, N., Al-Dahan, N., Al-Dosari, M., Bradley, D.A., Bukhari, S., Matthews, M., Regan, P.H., Santawamaitre, T., Malain, D., Habib, H. 2012.
Determination of the natural radioactivity levels in north west of Dukhan, Qatar using high-resolution gamma-ray spectrometry. Applied Radiation and Isotopes, 70: 1344-1350.

Al-Sulaiti, H. 2011. Determination of Natural Radioactivity Levels of the State of Qatar Using HighResolution Gamma-ray Spectrometry. PhD Thesis, 313 pp., University of Surrey, UK. http:// personal. ph.surrey.ac.uk/ phs1pr/phd_theses/.

Al-Sulaiti, H., Regan, P.H., Bradley, D.A., Malain, D. 2010. A preliminary report on the determination of natural radioactivity levels of the State of Qatar using high-resolution gamma-ray spectrometry. Nuclear Instruments and Methods in Physics Research, Section A: Accelerators, Spectrometers, Detectors and Associated Equipment, 619: 427431.

Amrani, D., Tahtat, M. 2001. Natural radioactivity in Algerian building materials. Applied Radiation and Isotopes, 54: 687-689.

Beretka, J., Mathew, P.J. 1985. Natural radioactivity of Australian building materials, industrial wastes and by-products. Health Physics, 48: 87-95.

Chen, S.B., Zhu, Y.G., Hu, Q.H. 2005. Soil to plant transfer of ${ }^{238} \mathrm{U},{ }^{226} \mathrm{Ra}$ and ${ }^{232} \mathrm{Th}$ on a uranium mining-impacted soil from south eastern China. Journal of Environmental Radioactivity, 82: 223236.

ESRI, 2005. ArcMap 9 from ArcView, 1999-2005, Environmental Systems Research Institute, Inc., CA., USA.

Genie, 2000. Basic Spectroscopy Software, Meriden, CT 06450, Canberra Industries, USA.

Hebinck, K., Middelkoop, H., Van Diepen, N., Van der Graaf, E.R., De Meijer, R.J. 2007. Radiometric fingerprinting of fluvial sediments in the RhineMeuse delta, the Netherlands - a feasibility test. Netherlands Journal of Geosciences, 86: 229-240.

IAEA, 2004. Application of the concepts of exclusion, exemption and clearance. In: Safety Standards Series No. RS-G-1.7. IAEA, pp. 1-29, Vienna, Austria.

IAEA, 1996. One decade after Chernobyl: summing up the consequences of the Accident. In: Proceedings of an International Conference, 8-12 April 1996, 555 pp., Vienna, Austria.

Ibrahim, F., Al-Hamarneh, M.I., Awadallah. 2009. Soil radioactivity levels and radiation hazard assessment in the highlands of northern Jordan. Radiation Measurements, 44: 102-110.

Kainan, S., Qiuju, G., Jianping, C. 2004. The effect of 
some soil characteristics on soil radon concentration and radon exhalation from soil surface. Journal of Nuclear Science and Technology, 41: 1113-1117.

Karunakara, N., Somashekarappa, H.M., Narayana, Y., Avadhani, D.N., Mahesh, H.M., Siddappa, K. 2001.

${ }^{137} \mathrm{Cs}$ concentration in the environment of Kaiga of south west coast of India. Health Physics, 81: 148155.

Kim, C.S., Lee, M.H., Kim, C.K., Kim, K.H. 1997. ${ }^{90} \mathrm{Sr},{ }^{137} \mathrm{Cs},{ }^{239+240} \mathrm{Pu}$ and ${ }^{238} \mathrm{Pu}$ concentrations in surface soils of Korea. Journal of Environmental Radioactivity, 40: 75-88.

Kumar, A., Kumar, M., Singh, B., Singh, S. 2003. Natural activities of ${ }^{238} \mathrm{U},{ }^{232} \mathrm{Th}$ and ${ }^{40} \mathrm{~K}$ in some Indian building materials. Radiation Measurements, 36: 465-469.

MOFA, 2007. General Information of State of Qatar. http://english.mofa.gov.qa/ details.cfm?id=6. [Accessed 02 July, 2011].

Nasir, T., Al-Sulaiti, H., Regan, P.H. 2012. Assessment of radioactivity in some soil samples of Qatar by gamma-ray spectroscopy. Pakistan Journal of Scientific and Industrial Research, 55: 128-134.

O'Brien, R. 2007. Barriers and burdens. In: IBC Third International Conference on Natural Radiation, IBC Global Conference, London, UK.

Park, K., Kang, T., Kim, W., Park, J.W. 2013. ${ }^{134}$ Cs and ${ }^{137} \mathrm{Cs}$ radioactivity in soil and moss samples of Jeju Island after Fukushima nuclear reactor accident. Applied Radiation and Isotopes, 81: 379-382.

Quindos, L.S., Fernandez, P.I., Soto, J., Rodeanas, C., Gomez, J. 1994. Natural radioactivity in Spanish soils. Health Physics, 66: 194-200.

Radhakrishna, A.P., Somashekarappa, H.M., Narayana,
Y., Siddappa, K. 1993. A new natural background radiation area on the southwest coast of India. Health Physics, 65: 390-395.

Rafique, M., Rehman, H., Matiullah, Malik, F., Rajput, M.U., Rahman, S.U., Rathore, M.H. 2011. Assessment of radiological hazards due to soil and building materials used in Mirpur Azad Kashmir, Pakistan. Iranian Journal of Radiation Research, 9: 77-87.

Rahman, S.U., Faheem, M., Anwar, J., Ziafat, M., Nasir, T., Matiullah, 2009. Assessment of external dose from the measured radioactivity in soil samples collected from the Islamabad capital territory, Pakistan. Journal of Radiological Protection, 29: 499-505.

Singh, S., Rani, A., Mahajan, R.K. 2005. ${ }^{226}$ Ra, ${ }^{232}$ Th and ${ }^{40} \mathrm{~K}$ analysis in soil samples from some areas of Punjab and Himachal Pradesh, India using gamma ray spectrometry. Radiation Measurements, 39: 431-439.

UNSCEAR, 2000. Sources of Ionizing Radiation. Annex B: Exposures from Natural Radiation, vol. 1, pp. 84-156, Report to the General Assembly, United Nations: New York, USA.

UNSCEAR, 1993. Sources, and Effects of Ionizing Radiation. Annex A: Exposures from Natural Sources of Radiation, pp. 33-90, Report to the General Assembly, United Nations: New York, USA.

UNSCEAR, 1988. Sources, Effect and Risk of Ionising Radiation. Annex A: Exposures from Natural Sources of Radiation, pp. 49-134, Report to the General Assembly, United Nations: New York, USA.

Wilson, W.F. 1994. A Guide to Naturally Occurring Radioactive Material (NORM), pp. 1-216, Penn Well Publishing Company, USA. 